\title{
Feministisk horror \\ - et studie i melodrama
}

Af Helle Hovgård Jørgensen

Massekulturens subgenrer porno, horror og melodrama begronser kvindelige subjekters udfoldelsesmuligheder. Men noir heltindens stemme og synsvinkel siver ned $i$ disse genver begynder genrernes dekonstruktion. Feministisk horror peger på problematiske strukturer og giver beltinder nye muligheder.

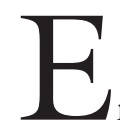

ngelske Sarah Dunants

Transgressions fra 1997 og amerikanske Susanna Moores in the cut fra 1995 er romaner, der selvbevidst trækker på subgenrerne porno, horror og melodrama. Begge romaner opererer med kvindelige subjekter og synsvinkler. Det er netop konstellationen af subgenrer, køn, krop og kvindelighed, der har vakt min interesse, og som jeg i det følgende vil analysere og diskutere.

Det er også omtalte konstellation, der umiddelbart făr mig til at rubricere romanerne som feministisk horror. Jeg kalder romanerne for feministisk horror, fordi jeg for det første ser subgenrestrukturernes dekonstruktion som en del af romanernes refleksionsniveau. Og på dette niveau betyder det, at selve det kvindelige subjekts muligheder og begrænsninger i omtalte genrer sættes i et perspektiv, der får afgørende betydning for fortolkningen af romanerne. For det andet bringes heltindens mulighed for at gribe styrende ind i handlingen, dvs. hendes offer- henholdsvis bøddelrolle, ind 
som en del af den centrale problematik i værkerne. For hvordan kan disse traditionelt kvindeundertrykkende subgenrer sige noget som helst interessant om det postmoderne kvindelige subjekts muligheder i 1990'ernes litteratur? Det vil jeg komme nærmere ind på i det følgende, hvor litteraturteoretikeren Peter Brooks' studie af melodramaet (1995) og filmteoretikeren Linda Williams' artikel "Film Bodies: Gender, Genre, and Excess" (1991) vil danne det teoretiske grundlag for en sammenligning af de to nævnte romaner. Elisabeth Bronfens teori om den hysteriske modus (1998) vil afslutningsvist blive inddraget som en yderligere perspektivering. Jeg vil først fokusere på det kvindelige subjekts muligheder for at styre handlingen, herunder også hendes muligheder for aktivt at gribe ind i sit eget liv. Dernæst vil jeg problematisere romanernes slutninger i lyset af melodramaet.

\section{MELODRAMATISK FORKLARINGSMODEL}

Jeg vil bruge melodramaet som forklaringsmodel for det kvindelige subjekts selvforståelse. Det vil jeg, fordi melodramaet har kroppen og den kropslige exces ${ }^{1}$ som sit erklærede og identitetsskabende fikspunkt. Men også fordi kroppen i den moderne tekstvidenskab er blevet analyseret og fortolket som det sted, psykiske konflikter indskriver sig, og som kilden til menneskets symboler. Tilegnelsen af kroppen er med til at gøre den ekspressiv, for hvis det skal være muligt at forstå kroppen, må den kunne leses. Det er således forholdet mellem krop og tekst i en psykoanalytisk referenceramme, der er i centrum for Peter Brooks' Body Work (1993). Her opfatter han kroppen som både objekt og motiv for narrationen. Man kan, som vi skal se, sige, at melodramaet legemliggør meningen, og det betyder, at kroppen gestikulerende, poserende og excessivt bliver det sted hvor "highly emotional messages that cannot be written elsewhere, and cannot be articulated verbally" indskrives. ${ }^{2}$
Da det klassiske scenemelodrama opstod i kølvandet på den franske revolution, havde det en vision. Den var dog samtidig en regression, idet den melodramatiske vision om, at det gode skulle uddrive det onde, også indebar en forkærlighed for svundne tider, og dermed en naiv forestilling om at vende tilbage til en tid, hvor alt kunne lade sig gøre, og hvor de gode altid ville vinde. Melodramaet skematiserede en idealiseret model for opførsel og en dybfølt sans for moral og anstændighed på baggrund af revolutionens kaos. Den melodramatiske ambition var, at alle fordækte relationer skulle afsløres, sandheden for en dag og retfærdigheden ske fyldest. Det klingede meget smukt alt sammen, men er selvfølgelig også stærkt forenklende, fordi det forudsatte en revolutionær moralisme, hvor det klart og entydigt fremgik, hvad der var godt (republikken) og hvad der var ondt (monarkiet). Det er med udgangspunkt i det klassiske scenemelodrama, at Peter Brooks definerer den melodramatiske modus som et spor, der er lagt ud i litteraturen. Han karakteriserer således den melodramatiske modus som "... a certain theatrical substratum used and reworked in the novelistic representation" (Brooks 1995, xiii).

Den melodramatiske vision er en hyldest til livet, og eros er melodramaets centrale, eksistentielle og nødvendige drift. Vi efterlades med en nostalgisk dimension, fordi forestillingen om det ondes uddrivelse indebærer en længsel efter en paradisisk lykketilstand, der skaber associationer til en forestilling om den magiske barndom og en oprindelig uskyldstilstand. Fundamentalt set handler det om tabet af ophav, dvs. udfrielse af symbiosen med moderen.

I det moderne melodrama er den nostalgiske dimension endnu mere udtalt. Derfor ender moderne melodramaer - "women's weepies"3 - sjældent lykkeligt eller med ægteskab (f.eks. filmene Titanic og The English Patient). Helte og heltinder dør og begæret efter, eller fantasien om, en genind- 
stiftelse af symbiosen forbliver uopfyldt. Franco Moretti fremhæver i sit essay "Kindergarten”, at det således især er sørgeligt, når foreningen med den anden uigenkaldeligt er for sent, dvs. over dødslejer eller kister $(1988,160)$. Det moderne melodrama er nemlig styret af en determinerende temporalitet, hvor heltinden for sent indser omfanget af sine fejltagelser. Det moderne melodramas betydeligste træk er det for sent, der erkendes hen imod fortællingens slutning, og som giver indtryk af noget irreversibelt og indgyder en længsel, der transcenderer nuet, og som kan fortolkes som nostalgi.

Den melodramatiske modus kan på baggrund af det ovenfor skitserede, lidt forenklet, siges at være karakteristisk ved: 1) sin fremstilling af kroppen som excessivt ekspressiv; 2) den melodramatiske visions moralisme og 3) den temporale dimension for sent, der bl.a. effektuerer en nostalgisk længsel.

\section{IDENTITETSSKABENDE SUBGENRER}

Linda Williams knytter melodramaet sammen med subgenrerne porno og horror, idet alle tre genrer er centreret om en groft fortegnet fremstilling af menneskekroppen. Det vil i hendes sammenhæng især sige kvindekroppen. Williams perspektiverer, hvordan genrerne griber ind i fantasien, så de ligefrem kommer til at virke strukturerende for forståelsen af kønsidentiteten, idet hun mener, at genrerne gennemspiller og repeterer nogle fantasier, der reflekterer myterne om identitetens oprindelse.

Vi konfronteres altså med tre forskellige gåder i de tre forskellige subgenrer, der alle berører nogle oprindelige fantasier:

\section{1) Gåden om oprindelsen af det seksuelle begar.}

Gådens løsning: fantasien om forførelse.

Genre: Porno: endeløse repetitioner af fantasien om den primale forførelse, der udmøntes i endeløse møder med den anden.
Forførte og forfører befinder sig i et idealt pornotopia, hvor det altid er sengetid.

Tempus: on-time.

2) Gåden om den seksuelle forskel. Gådens løsning: fantasien om kastration.

Genre: horror: endeløse repetitioner af fantasien om kastration, som om gentagelsen skulle bemestre og forklare det oprindelige problem med den seksuelle forskel.

Tempus: too-early.

3) Gåden om selvets oprindelse.

Gådens losning: fantasien om familie romancen eller tilbagevenden til ophavet.

Genre: melodrama: endeløse repetitioner af den melankolske fornemmelse af tabet af ophav, der skitserer et umuligt håb om at vende tilbage til et tidligere stadie, som fundamentalt set representeres af moderkroppen. Tempus: too-late.

Linda Williams tilskriver genrerne en strukturerende temporalitet for at demonstrere deres utopiske bestræbelse på at løse de tre forskellige gåder. I porno finder mødet med den anden altid sted "on time", så subjekt og objekt (den forførte og forføreren) mødes i gensidig nydelse. I horrorgenren finder mødet sted for tidligt, hvor det endnu ikke seksuelt parate subjekt møder monsteret, før hun er parat og det dør man af $\mathrm{i}$ den genre (tænk på forste mordscene $\mathrm{i}$ Wes Craven's Scream (1995)). I melodramaet finder mødet som sagt sted for sent. Det bliver en hyldest til den lykke, der vinkes farvel til. Således ophøjes lidelsen til en dyd i melodramaets strukturer. Der er altså et subversivt, utopisk element i erkendelsen af, at det oprindelige, man længes efter, uigenkaldeligt er tabt. Det er ikke kun en form for passiv magtesløshed. Fantasien om, at mødet med den anden altid allerede er for sent, er baseret på en utopisk tro på, at det trods alt aldrig er for sent at genforenes med den anden, der en gang var en del af en selv. Det er den dobbelthed, der giver melodramaet dets dynamik. 
Genrerne virker altså strukturerende for en moderne bevidsthed og fungerer således som kulturelle problemløsere. Linda Williams påpeger, at genrernes stadige tilstedeværelse i kulturen vidner om hårdnakketheden af de problemer, de fokuserer på, og problemerne relaterer sig altså til forestillingen om oprindelsen af det seksuelle begxr, den seksuelle forskel og selvet. Fascinationen knyttes hermed til selve identitetstilblivelsen, og både det epistemologiske og det seksuelle begær indskrives som narrative motorer.

Det er den temporale mekanisme, der giver både Transgressions og in the cut en melodramatisk slutning selv om de umiddelbart tager sig ud som horror fiktion. Horrorens temporale bestemmelse er, som jeg nævnte: for tidligt. Men eftersom den ikke effektueres i Transgressions og heller ikke dominerer i in the cut's sidste scene, vil jeg især diskutere det melodramatiske genreperspektivs betydning for heltindernes muligheder og begrænsninger.

Alligevel ligger de i samme blodige kølvand som så mange andre postmoderne horrorfortællinger i 1990'erne, der sensationelt indledtes af Bret Easton Ellis' American Psycho fra 1991. Som det er tilfældet med så mange andre af disse fortællinger, har de to romaner jeg her beskæftiger mig med, fire frelles temaer. Enhver postmoderne horrorfortælling med respekt for sig selv har synet som vigtigste sans; sex fremstillet utilsløret som porno performance; seriemorderen som det ultimativt onde og virkeligheden som et grænsefænomen. Synet, sex, seriemord og en uklar forestilling om virkeligheden er faste ingredienser i mange af 1990'ernes horrorfortællinger. Massekulturen er interteksten så at sige, altså den tekst eller kontekst, subjektet er i dialog med, der er sammensat af litteratur, film, musik og massemedier. Og kroppen er det centrale topos.

\section{TRANSGRESSIONS OG IN THE CUT}

De to romaner, jeg vil sammenligne, har begge kvindelige forfattere og fortællerstemmer. Heltinden er den attraktive single på nogen-og-tredive, der er intelligent, veluddannet, seksuelt frigjort og økonomisk uafhængig. Hun er optaget af seksuelle overskridelser, hvad enten de stammer fra fiktionen, fantasien, den omgivende virkelighed eller hendes egen intimsfære.

Begge romaner har storbyen som den topografiske ramme om fortællingen, henholdsvis New York og London. Den urbane realisme, som forudsættes, leverer forestillingen om storbyens anonymitet, hvor fremmedfølelsen overfor andre mennesker således udvikler sig til en paranoid angst for at være forfulgt og overvåget. Det betyder i begge romaner, at det kvindelige subjekt er sårbart og udsat. Derudover er storbyen den perfekte topografiske ramme om en horror roman, fordi den er sammenlignelig med det gotiske slot. ${ }^{4}$ Som det gotiske slot er storbyen også afgrænset af høje mure, klaustrofobisk, labyrintisk, mørk og uhyggevækkende.

I begge romaner er en anden tekst skrevet ind i fortællingen. I Transgressions oversætter heltinden en gammeldags krimi af den slags, hvor mand redder kvinde. I in the cut arbejder heltinden på en bog om gadeslang. Begge former for tekst benytter sig af et sprog, der er langt mere voldeligt og seksuelt orienteret end det sprog, den primære fortælling benytter. Inddragelsen af den anden tekst fungerer umiddelbart som kompensation for heltindernes eget mere sofistikerede sprog vedrørende vold og sex. Men den leverer selvfølgelig 


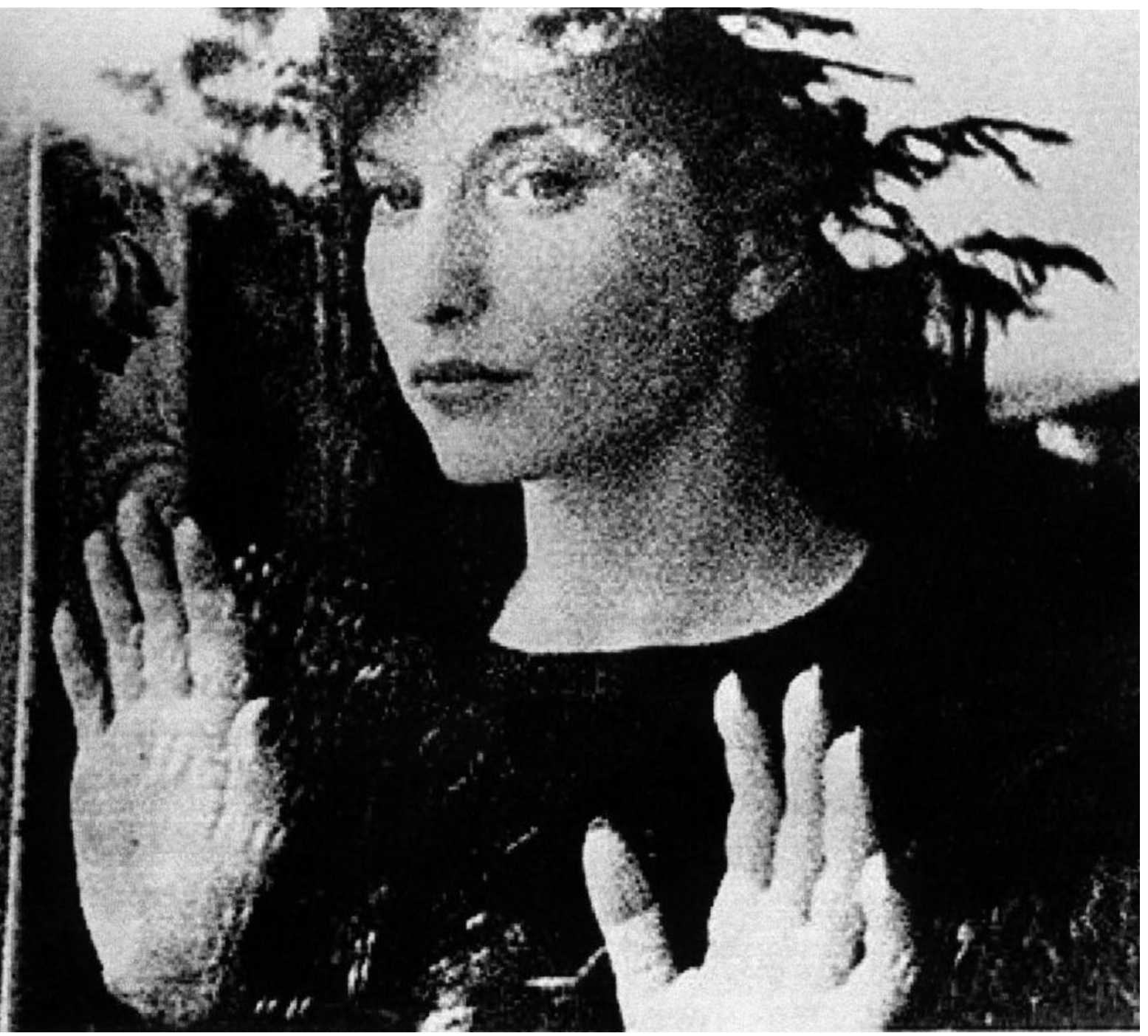

Maya Deren i Meshes in the Afternoon, 1943 
også effektivt en perspektivering af det kvindelige subjekts forhold til virkeligheden, og til hendes kønsidentitet.

in the cut's kvindelige protagonist er Frannie, der underviser i "creative writing" på New York University og arbejder på en bog om gadeslang. Hun indleder et forhold til politimanden Malloy, som efterforsker mordet på en kvinde. Frannie tror, at han selv er morderen, fordi hun inden drabet har set kvinden sammen med en mand, der har samme tatovering som Malloy. Hun tager fejl og myrdes brutalt i fortællingens slutning.

Heltinden i Transgressions er Elizabeth, som bor alene $\mathrm{i}$ et stort hus i London efter et bittert brud med sin kæreste gennem syv år. Hendes eneste selskab er en kat og en hårdkogt tjekkisk krimi, som hun er i færd med at oversætte. Krimiens handling ridses op som tekstuddrag i det primære plot. Krimien handler om den amerikanske betjent Jake, der rydder op i Østeuropa, og om hans ekskone Mirka, der bliver taget som gidsel af den østeuropæiske mafia. Oversætteren Elizabeth indleder i romanens forløb et noget særpræget forhold til en mand, efter at han flere gange er trængt ind i hendes hus og har flyttet rundt på forskellige ting. Forholdet kan man med sans for moderne kærlighedsterminologi kalde intenst, besættende og grænseoverskridende fra deres første møde, hvor han har til hensigt at voldtage hende, og til hun finalt myrder ham. Men det er først, da hun er i færd med at slå ham ihjel, at hun faktisk indser, at han ikke er den, hun troede, han var. Han er ikke seriemorderen, dvs. den ultimativt postmoderne onde, men blot en ulykkelig og forpint mand, der er blevet besat af hende.

Jeg vil i det følgende analysere det, jeg kalder vendepunktet i Sarah Dunant's Transgressions, og dens melodramatiske slutning. Undervejs vil jeg perspektivere og sammenligne med in the cut. For hvorfor overlever Elizabeth i de samme genrer som Frannie dør i?

\section{VENDEPUNKTET}

I Transgressions udgør den scene, der skulle have været en voldtægt, et vendepunkt, fordi heltinden redder sig selv ved at forføre den unavngivne og ubudne gxst, der sidder $i$ fodenden af hendes seng, da hun en nat vågner: "She never knew what woke her ..." (Dunant 1997, 171), men til sin kæmpestore rædsel opdager hun en fremmed $\mathrm{i}$ fodenden. Han har tilmed en hammer i hånden. Hun overtager imidlertid styringen: rollerne byttes om eller ligestilles. I slutningen af kapitlet, der indeholder omtalte scene, konstateres det: "And so she got up and very slowly started to get on with the rest of her life" (ibid., 189). Men herfra er der nogle fundamentale betingelser, der er ændret. For det første ved hun nu, hvad det er, der bryder ind i hendes hus, og at hun igennem lang tid er blevet overvåget $\mathrm{i}$ sin have, på terrassen og $\mathrm{i}$ de oplyste vinduer. For det andet vil hun have hævn.

Vendepunktet bibringer heltinden nødvendig viden om hendes situation og den grænseoverskridende handling muliggør hendes transformation. Fra at være til skue for et mandligt blik, bliver hun nu aktivt seende: "she became the voyeur" (ibid., 252). Heltindens egen aktive indgriben $\mathrm{i}$ sin skæbne problematiserer hendes offerrolle så meget, at hun ikke melder voldtægten til politiet, for på en eller anden ubegribelig måde er det, der er sket mellem dem: “... more intimate than violence ...", og hun ved "... that she would never be able to tell it" (ibid., 188). Men affæren inspirerer hende også til at gribe aktivt ind i den roman, hun oversætter. Omvendt kommer romanen til at gribe ind i det liv, hun lever.

Frannie fra in the cut griber derimod ikke på noget tidspunkt aktivt ind i hverken den tekst, hun arbejder med, eller den verden, der omgiver hende. Som fortællingens subjekt distancerer hun sig fra den omkringliggende virkelighed ved at forholde sig analyserende til alt, hvad hun ser. Hun bliver opsøgt, overvåget, forført og lader sig domi- 
nere af sin fascination af det mandeunivers, machoheltetypen, hendes elsker Malloy repræsenterer. Hun er på én gang tilskuer og til skue. Af mange grunde ender hun som et passivt offer. En væsentlig grund er, at hendes syn er dårligt. I en udprxget visuel kultur er det fatalt. Symbolsk betyder det også, at hun ikke kan afkode de tegn omverdenen, dvs. byrummet og andre mennesker, leverer. Efter at hun overværer det, der i melodramaet kaldes en "fordækt relation", i en kælder, ender hun selv som den, der føler sig overvåget. Den fordækte relation udformer sig for heltindens øjne som et narrativt tableau. Det fremstiller en fellatio scene, hvor manden sidder tilbagelænet i en sofa, og kvinden ligger på knæ mellem hans ben, og således udfører den seksuelle transaktion. Fallos er i det narrative tableaus centrum. Manden ser ud på Frannie, så hun ikke kan opretholde sin voyeur status, fordi tableauet sådan set "ser igen". Mandens ansigt er delvist skjult af mørket i rummet, og i ly af dette fastholder han Frannies blik. Han kan altså tydeligt se hende, som hun står i den oplyste døråbning, men hun kan ikke se hans ansigt. Frannie føler sig korsfæstet af mandens blik, men også overvåget i en generelt ubestemt betydning: “... looking over my shoulder, suddenly afraid someone had seen me ..." (Moore 1995, 21). Hun er altså umiddelbart placeret mellem det falloscentriske blik og overvågningsfantasmets kulturbestemte patriarkalske blik. Hun flygter fra scenen uden at få kontrol over synsakten. Mødet med den formodede seriemorder bibringer hende altså ingen form for nyttig viden. Frannie griber ikke aktivt ind i sin omverden, men registrerer den blot. Det gxlder også forholdet til sproget, som hun forholder sig intellektuelt og akademisk til. Med sine lister over gadeslang ønsker hun at kontrollere den del af virkeligheden, som hun som udgangspunkt ikke har adgang til.

Elizabeth derimod ændrer den tekst, hun har med at gøre. Hun gør kvinden Mirka til subjekt i en krimi, hvor Jake er helten, den hårdkogte detektiv, og hvor Mirka egentlig var tiltænkt rollen som traditionelt objekt og offer. Elizabeths indgriben i fiktionen kommer til at afspejle virkeligheden. Inspireret af sin egen forførelse af den fremmede, xndrer hun handlingen i romanen, hun oversætter, så Mirka forfører sin fangevogter, erobrer den falliske kniv og gør fangevogteren ukampdygtig. Hun redder med andre ord sig selv, hvor det oprindeligt var meningen, at helten Jake skulle redde sin kvinde. Men romanen bliver også spejl for virkeligheden, for finalt slår Elizabeth sin ubudne grest ihjel med en saks.

Den farlige kvinde (eller den ligefrem kastrerende kvinde), der slår mænd ihjel med spidse genstande, er et tema Hollywood tog op i filmen Basic Instinct (1992), og som romanen selvbevidst refererer til allerede side 37 . På samme måde er kattens tilstedeværelse suspensskabende. For hvornår bliver det lille pelsdyr Millie slagtet? Også denne indirekte reference til en film (Fatal Attraction (1987)) gøres eksplicit, da Millie bliver såret og senere dør: "A trap. It was such a viciously corny piece of revenge, more befitting for a bad movie than real life. Hit the family where it hurts. Boil the rabbit. But for all its melodrama it had worked. Millie was her family" (Dunant 1997, 279). Intertekstens aktualisering i den primære tekst og den udtalte bevidsthed om intertekstens betydning er med til at danne subjektets meget selvbevidste mulighed for at gribe ind $\mathrm{i}$ handlingen. $\mathrm{Al}$ anden tekst, der inddrages i fortællingen, er altså både styrende for og styret af plottet. Romanen opererer med en udtalt metafiktiv bevidsthed, der er med til at bryde genrernes konformitet.

in the cut leverer på den anden side en desillusioneret forestilling om, at det ikke er muligt at xndre det sproglige system, der dominerer det kvindelige subjekt. Hun sidder fast i såvel de sproglige strukturer som i genrestrukturerne. Transgressions er altså anderledes optimistisk. Her fremstilles muligheden for, at heltinden kan blive fri af 
de dominerende genres undertrykkelse ved at træde i karakter som aktivt og målbevidst kvindeligt subjekt. Er løsningen på subgenrernes problematiske kønsperspektiv, at rollerne byttes om, så kvinderne bliver bødler?

Hvis subgenrerne er identitetsskabende, som Linda Williams pointerer, er det vigtigt med troværdige figurer at identificere sig med, også for kvinder. Heltinder der kan beundres for deres vovemod og kvindelighed, er vigtige i den massekulturelle strøm.

En trash roman som den, Elizabeth oversætter, fremstilles som et eksempel på, hvordan det gør en forskel, om subjektet er mand eller kvinde. Helten (Jake) beskriver således heltinden (Mirka) metonymt, som et par strittende brystvorter i en grøn kjole (ibid., 293). Men da heltinden (med Elizabeths hjælp) bliver subjekt og overtager fortællingen, trænger vi også ind i hendes bevidsthed, og det objektiverende fokus slippes midlertidigt. Således oscillerer vi i afsnittet side 203-208 mellem Mirkas bevidsthed og fangevogterens blik. Så selv om fortælleren siger: “you probably wouldn't even notice the joins" (ibid., 202), opdager vi selvfølgelig, at plottet er ændret, fordi vi lige forinden er blevet gjort opmærksom på følgende: "Now it was the season for the women to wake in the night and find their own voices to put against men's". Med en lille omskrivning af Virginia Woolfs klassiker for den feministiske bevægelse: $A$ Room of One's Own (1929), skal man ikke undervurdere projektet, der i denne sammenhæng illustrerer det kvindelige subjekts problem som det at få "a voice of one’s own". Det giver Elizabeth Mirka (igen side 241-244). Trods det får Jake det sidste ord, og krimiens melodramatiske forventning opfyldes: det onde er udkæmpet og parret resitueret i den gode xgteskabelige orden, for, som Jake siger, "A hard man is good to find"! Sådan vil de ha' det - kvinderne, siger altså Jake!

Elizabeth kommer til kort overfor slutningen og målgruppen: “Give her (Mirka) body, but no brain. Remember whom you are writing for" (ibid., 291). Ægte trash må leve op til den klassiske melodramatiske forventning om muligheden for at forenes med den eneste ene. Alligevel får Mirka også sin stemme igennem i krimiens slutning, da hun siger: "No, fuck you. Fuck you, Jake, and all your Superman fantasy. You want me sit around and wait till you burst in like something from an action movie? Well, I didn't want to be saved by you. You understand? I wanted to save myself" (ibid, 296). Lidt senere siger hun: "No, you don't Jake. You love the idea of me" (ibid, 297). Hendes seksualitet og krop får således betydning som andet end et besiddelsesobjekt. Alligevel indstiftes pornoens temporalitet ("on time") i afslutningen på Mirka og Jakes eventyr, og de mødes i et idealt pornotopia, hvor det med Williams ord altid er sengetid: "He turned her over. What? You think we're going to sleep now? And he slid his hand down towards her" (ibid, 304). Kønsperspektivet er stadig problematisk. Også slutscenen er centreret om eksponeringen af den lystfyldte kvindes krop.

\section{DEN MELODRAMATISKE SLUTNING}

Transgressions adskiller sig fra sine hårdkogte forgængere i genren ved at melodramatisere slutningen på en måde, der gør manden til det medlidenheds-vækkende offer. Det er også mandekroppen, der udstilles mest ekscessivt, da han med sit blottede køn løber frem mod den saks, Elizabeth har $\mathrm{i}$ hånden, $\mathrm{og}$ som dræbende trænger ind $\mathrm{i}$ hans underliv. På melodramatisk vis indser hun for sent, at han ikke er den seriemorder, hun troede, han var, men et menneske, der ønskede hendes opmærksomhed, og som var ulykkeligt forelsket i hende. Hun røres af den erkendelse på en måde, der gør hende omsorgsfuld og forstående. Hans andet voldtxgtsforsøg mod hende kort forinden tilgives og udviskes af den pludselighed, hvormed deres symbiotiske forening effektueres af hans smerte: "Suddenly, it was as if someone had turned out all the 
other lights in the world; they were alone together, .... Just a man and a woman squeezed into the stillness between the hands of the clock, all their energy focused on his pain ..." (ibid., 366). Hans smerte er helt konkret forårsaget af den saks hun netop har stukket i ham, men mimer også den traumatiske smerte, der er forbundet med erkendelsen af tabet. Hun sammenligner deres forening i hans død med deres samleje ved første møde: “... she pulled her arm around his shoulders, bending her body over him until her head was cradled next to his. It was like the end of their lovemaking, when she had hugged him and he started to cry. She should have known then that he wasn't a killer" (ibid., 366-367).

Hun har forvoldt ham smerte, og den erkendelse får hende paradoksalt nok til at ønske at redde ham eller i hvert fald beskytte ham mod mere ondt: "He stood rigid against her, his eyes staring into hers, as if trying to work out how it was that she could have hurt him so much, .... She had to put her arms around him to stop him from crashing to the ground." (ibid.). Hendes (makabre) omsorg ligner den elskendes omsorg for den elskede eller en moders omsorg for sit barn. Symbiosen og den effektive erkendelse af for sent leder tankerne hen på det melodramatiske element af nostalgisk længsel efter den oprindelige symbiose med moderkroppen. Hans død efterlader hende da også med en følelse af både tomhed og forløsning. En fødsel kan også karakteriseres ved en form for tomhed (fosteret er udskilt fra moderkroppen) og forløsning (et nyt liv begynder). Døden knyttes altså sammen med både den seksuelle forening og fødslen. I den finale forening/ forløsning udfries Elizabeth fra sin besættelse. Som hans sperm blev udvasket af hendes menstruationsblod efter deres første samleje, bliver hans blod nu sammenlignet med "the first wild flow of menstrual blood" (ibid., 366). Menstruationsblodet udrenser livmoderen, som han nu symbolsk udrenses fra hendes liv. Hun er fri af sin be- sættelse, sin monstrøse skabning, sit modsatrettede begær og føler sig: "Safer and emptier" (ibid., 374). Den seksuelle ekstase, fødselsøjeblikket og dødsøjeblikket sidestilles med andre ord i et fælles fikspunkt, hvor smerte og forløsning smelter sammen og efterlader en følelse af tomhed.

Deres forholds dramatiske afslutning har sin styrke i denne kobling af horror og melodrama og kan bedst karakteriseres som monstrøst. Deres forening har ikke skabt liv. Det fremhæves med menstruationsblodets tilstedeværelse efter samlejet og som det symbolske udtryk for hans død. Blodets voldsomhed i den sidste sammenhæng leder tanken hen på mislykket graviditet og understreger altså moderskabets fravær.

Det monstrøse er således indirekte knyttet til flere former for skabelse. Han kan læses som hendes skabning, på samme måde som detektivhistorien bliver hendes værk: et produkt af hendes bevidsthed og fantasi. En kombination af virkelighed og fiktion, der skaber et monster af frankensteinsk format, der indgyder skaberen både had og kærlighed, foragt og fascination. Skabningen/monsteret viser sig på uhyggelig vis og opfører sig ikke, som det var tiltænkt. Det forsvinder ikke af sig selv, men forfølger sin skaber. Det monstrøse barn er uelskværdigt og af samme grund medlidenhedsvækkende. I sidste instans er et metafiktivt aspekt involveret, hvor forfatterens forhold til sit værk udstilles. Det ambivalente forhold til subgenrerne er også involveret.

I in the cut indtreffer heltindens erkendelse af fejltagelserne også for sent. For sent indser Frannie, at hun er havnet i den forkerte bil med den forkerte mand. Ham, hun troede var seriemorderen, viser sig $\mathrm{i}$ virkeligheden at være den eneste, der kunne have reddet hende, hvis hun ikke på melodramatisk vis havde tilbageholdt viden for ham og oven i købet selv havde bundet ham til en stol i sin lejlighed. I det øjeblik, hun ser klart "I saw these things very precisely, very exactly ...” (Moore 1995, 258), 
er det for sent. Hun indser, at hendes død er direkte forårsaget af, at hun ikke har genkendt manden fra fellatio scenen. Han viser sig nemlig at være seriemorderen, og han troede, hun havde genkendt ham og derfor ville være $i$ stand til at afsløre ham. Da han er i færd med at skære hende op, siger han: "... I thought you recognized me", hvortil Frannie svarer "No" og tænker "I felt sad" (ibid., 262). Hendes død er med andre ord også en fejltagelse. Hun erkender slutteligt, at hendes uvidenhed og passivitet har gjort hende ubeskyttet mod det onde. På det tidspunkt, hvor hun opnår den nødvendige viden, er det for sent. Det onde overvindes ikke som i Transgressions. Frannie dør! Trods sin åbenlyse offerstatus får Frannie indirekte sin stemme igennem i romanens allersidste sætning, og den kan derfor også kaldes feministisk horror. Det snæversynede nutidsperspektiv skiftes ud med en retrospektiv synsvinkel, da jeg'et bliver til hun. Først i romanens sidste sætning tager heltinden sin kvindelige subjektivitet på sig, og peger på den måde på det problematiske ved subgenrernes kvindeundertrykkende strukturer. Frannie går med andre ord til grunde, fordi hun midlertidigt har taget ophold i de mandsdominerede subgenrestrukturer.

I modsætning hertil står Elizabeth som horrorheltinde i den melodramatiske slutning. Hun har grebet det falliske instrument og spidder drabende manden. Hun er både sejrende og sørgende. Slutningen åbner for en ny begyndelse til lydsporet: "The healing has begun".

I genrer, hvor det seksuelle begær utvetydigt og åbenlyst er indlejret i sproget: "The words flowed like genital juices" (Dunant 1997, 242) og koblet til den ekstreme vold og voldsomme død, bliver kroppen, hvad enten den er en mands eller en kvindes, fortællingens vigtigste topos. Her kulminerer handlingen, når genrerne finalt flyder sammen som de tilhørende kropsvæsker: blod, tårer og seksuelle safter. Det ultimative skue bliver den ekscessive åbne krop, der således kan berette om en hudløs sårbarhed, hvor det indre eksternaliseres, hvor identitetens kerne bogstaveligt forsøges afdækket og psykiske konflikter (som f.eks. hysteriet) indskrives. Den åbne krop vidner om en følsomhed, der skal tages alvorligt. Patos bliver således centralt $\mathrm{i}$ det horrible melodramas fremstilling af kroppen. Lidelsen og højemotionelle beskeder, hyperbolsk fremstillet, forbinder det melodramatiske kropslige udtryk med hysterikerens performance og bestræbelse på at: "åbne op" frem for at "dække til".5

På baggrund af Elisabeth Bronfens teori om den hysteriske modus læser jeg horrorgenrens gentagne åbning af kroppe som et forsøg på kødeligt at dykke ned i "the fissure between total visuality ... and the invisible 'other scene' of the unconscious" (Bronfen 1998, 176). Den horrible opskxring af kroppen i in the cut er også både pornografisk og melodramatisk, da kropsvæskerne finalt blandes. Kvindekroppens åbning bliver tvetydig idet seksualiseringen er konkret $\mathrm{i}$ in the cut. Selve titlen er et brudstykke af en sætning i romanen, hvor Malloy under et samleje med Frannie siger: "I like it in the cut" (Moore 1995, 251). Det betyder helt konkret, at han kan lide at se penis trænge ind i kvindens skede. Da "cut" også betyder at skære, forbindes det at skære med noget seksuelt og kvindens kønsåbning med et åbent sår. Sex bliver således en blodig affære, hvor der fokuseres på kvindekroppens åbning i mere end en forstand. "Cut" kommer i den sammenhæng til at rime på "cunt" (kusse). Kvindens krop er altså altid allerede åben og derfor velegnet som den primære legemliggørelse af den kropslige exces. Kønsåbningen kan læses som den sprække, der er fuldt synlig, men samtidig dækker over det oprindelige hjem. Opskxringen af kroppen er altså yderligere et forsøg på at trænge ind og opklare mysteriet om den seksuelle forskel, identiteten og begæret. På den måde blandes genrerne også.

Huden opretholder illusionen om indivi- 
det som en helhed, og med hudens perforering og kødets og blodets eksponering demonstreres kroppens radikale åbning også som en symbolsk afdækning af de traumatiske forhold, der vedrører de utopiske forhold forbundet med den seksuelle forskel, begæret og identitetstilblivelsen. ${ }^{6}$ Det vil sige horrorens gåde om den seksuelle forskel, der kan manifesteres som opskæring eller åbning af kroppe, kan læses som en kastrationsfantasi. Men samtidig læser jeg åbningen af kroppen som et forsøg på at finde ind til identitetens kerne - vel vidende at en sådan helhed intet sted findes. Det bliver altså muligt at læse den kødelige åbning af kroppen som en ultimativ gestus, der kan fortolkes som hysterisk. Koblingen af subgenrerne til den hysteriske performance er med til at understrege subgenrernes kønsproblematiske og identitetsskabende perspektiver, fordi hysteriet også stigmatiserer især kvinden og tildeler hende offerrollen. Men den feministiske horrors selvbevidste anvendelse af omtalte subgenrer og det kvindelige subjekts erkendelse af sin rolle under patriarkatet som offer, gør det muligt at anlægge en feministisk synsvinkel, hvor subgenrerne også virker subversivt. Det betyder, at den feministiske horror gør op med genrekonventionernes lovmæssigheder i lighed med hysteriet: "Indeed, the resilience of hysteria as a symptom ... lies in its conflating a refusal to decide between masculinity and femininity with an oscillation between proving the law of sexual identity and protesting against the oppression of that very same law." (Bronfen 1998, 185) I denne sammenhæng vil det sige, at den bruger de etablerede genrestrukturer for at bryde med selv samme strukturer og konventioner i bestræbelsen på at forny dem. På den måde kommer den feministiske horror til at pege på genrernes kønsproblematiske strukturer og tilbyder samtidig et fornyet syn på det kvindelige subjekts muligheder.

\section{NOTER}

1. Med kropslig exces mener jeg, at den melodramatiske modus fremstiller kroppen ude af sig selv eller ude af kontrol, dvs. i ekstase, men der finder også en mere konkret grænseoverskridelse sted, idet kroppen åbnes: tårer strømmer ud eller munden åbnes. I yderste konsekvens åbnes kroppen med vold og grænserne for ydre og indre brydes op.

2. Brooks i det nye forord til 1995 udgaven af The Melodramatic Imagination: Balzac, Henry James, and the Mode of Excess. (opr. fra 1976).

3. Betegnelsen er en blanding af to gængse betegnelser ("the woman's film" og "weepie") for de melodramaer Linda Williams definerer som: "addressed to women in their traditional status under patriarchy - as wives, mothers, abandoned lovers, or in their traditional status as bodily hysteria or excess, as in the frequent case of the woman "afflicted" with a deadly or debilitating disease" (Williams 1991, 4). Endvidere henviser hun til Christine Gledhill's introduction til antologien Home is Where the heart is: Studies in Melodrama and the Woman's Film (1987), Peter Brooks' (1976): The Melodramatic Imagination og Mary Ann Doane (1987): The Desire to Desire.

4. Det gotiske slot forstået som den centrale litterære topografi i gotiske romaner fra slutningen af 1700-tallet og frem. Horace Walpole's The Castle of Otranto (1764) regnes som den første af slagsen. Om det gotiske slot som struktureringsprincip i romaner se M.M. Bakhtin (1973): "Forms of Time and Chronotope in the Novel" in The Dialogic Imagination (1981), University of Texas Press, Austin (245-246).

5. Her refererer jeg til en forelæsning, Elisabeth Bronfen holdt på Ph.d. seminaret Body, Text, Image den 22. september 1998 i Vissenbjeg om Bram Stokers Dracula. Der fremhævede hun hysterikerens endeløse bestræbelse på at pege på "what is rotten in the law" ved at henvise til, at hysterikeren netop hele tiden forsøger at åbne eller afdække de traumatiske forhold. Se endvidere Elisabeth Bronfen (1998): The Knotted Subject. Hysteria and its Discontent, Princeton University Press, New Jersey. 6. Her kobler jeg Williams genreteori med Bronfens teori om hysteriet. Bronfen siger i introduktionen til The Knotted Subject: "My interest lies in hysteria as a structuring of the subject, as a strategy using multiple selffashionings .... That is, the structure comes from (yet also screens out) the traumatic kernel at the core of all systems of identity, the Urverdrängung, on which all later repressions, phantasy work, and symptom formation feeds without ever directly touching it." (35) 


\section{LITTERATUR}

- Annesley, James (1998): Blank Fiction. Consumerism, Culture and the Contemporary American Novel. Pluto Press, London.

- Bronfen, Elizabeth (1992): Over Her Dead Body. Routledge, New York.

- (1998): The Knotted Subject. Hysteria and its Discontent. Princeton University Press, New Jersey. - Brooks, Peter (1976, New Preface 1995): The Melodramatic Imagination: Balzac, Henry James, Melodrama, and the Mode of Excess. Yale University Press, New Haven.

- (1993): Body Work. Harvard University Press, Cambridge, Massachusetts.

- Doane, Mary Ann (1987): The Desire to Desire: The Woman's Film of the 1940's. Bloomington, Indiana University Press.

- Dunant, Sarah (1997): Transgressions. Virago Press, London.

- Knudsen, Britta Timm (1992): "Mellem maskerade og simulakrum - en (billed)teori om det kvindelige", in Maskerade, Kulturstudier 16, Århus Universitet.

- Kristeva, Julia (1966): "Word, Dialogue and Novel" in Toril Moi (ed.) The Kristeva Reader. Basil Blackwell, Oxford.

. Laplanche, Jean og Pontalis, J.B. (1968): "Fantasy and the Origins of Sexuality", in The International Journal of Psycho-Analysis, vol.49.

- Marcoux, J. Paul (1992): Guilbert de Pixerécourt: French Melodrama in the Early Nineteenth Century. Peter Lang Publishing, Inc., New York.

- Modleski, Tania (1991): "Femininity as

Mas(s)querade", in Feminism without Women:

Culture and Criticism in a "Postfeminist" Age.

Routledge, New York \& London.

- Moore, Susanna (1995): in the cut. Onyx, The Penguin Group, New York.

- Moretti, Franco (1988): "Kindergarten", in Signs Taken for Wonders: Essays in the Sociology of Literary Forms. Verso, London \& New York.

- Prendergast, Christopher (1978): Balzac: Fiction and Melodrama. Edward Arnold Ltd., London.
· Riviere, Joan (1992, opr. 1929): "Kvindelighed som maskerade", in Maskerade, kulturstudier 16, Århus Universitet.

- Russo, Mary (1994): The Female Grotesque: Risk, Excess and Modernity. Routledge, New York.

- Sabiston, Elizabeth Jean (1987): The Prison of Womanhood. The Macmillan Press Ltd., London.

- Svane, Marie Louise og Tania Ørum (1991): Køn og moderne tider: En antologi. Tiderne Skifter, København.

-Williams, Linda (1991): "Film Bodies: Gender, Genre, and Excess", in Film Quarterly, summer vol. 44: 2-13.

- Young, Elisabeth \& Graham Caveney, eds. (1992): Shopping in Space: Essays on American “Blank Generation” Fiction. Serpent's Tail, London.

\section{SUMMARY}

On the basis of Peter Brooks' study of the melodramatic mode, the article compares Sarah Dunant's novel Transgressions (1997) and Susanna Moore's novel in the cut (1995). The sub genve study by Linda Williams is engaged to explore the obvious horrific and pornographic elements of the novels. The excessive female body is in the centre of such a study and this aspect is elaborated by Elisabeth Bronfen's theorising of the hysteric performance. The theoretical trio is applied to analyse the melodramatic endings of the novels and their horrific and pornographic openings of bodies.

Helle H. Jørgensen, mag. art., ekstern lektor, Syddansk Universitet, Odense 